\title{
LISTENING COMPREHENSION PROBLEMS AMONG EFL VOCATIONAL SCHOOL STUDENTS
}

\author{
Nurhandayani Supraptiningsih, Eliza Nur Fadila, Zuhad Ahmad \\ University of Muhammadiyah Prof. Dr. HAMKA \\ nurhandayani@uhamka.ac.id, elizanurf@gmail.com,zuhad_ahmad@yahoo.com
}

\begin{abstract}
Listening to a conversation, dialogue, or a story in foreign language is an activity which needs effort to understand the content. There are several aspects that should be considered to do accordingly. This research investigated the main problems of listening comprehension in English as a foreign language faced by vocational high school students. Thirty students of the first grade participated in the research. The quantitative descriptive and qualitative methodologies were applied in this study with questionnaires and interviews used as instruments for collecting data. The findings show that the foremost problems of understanding the spoken text are the unfamiliar accents and topics. The other problems also have contribution to the students' comprehension. They are noises, poor quality equipment, long spoken text, and the high speed of delivery. The findings of this study is expected to provide valuable information for English teachers regarding the listening difficulties faced by English as a foreign language students, which enable them to help students to improve their listening skills.
\end{abstract}

Keywords: Listening, Listening Comprehension, Listening Comprehension Problems

\section{INTRODUCTION}

Listening comprehension in English as Foreign Language (EFL) context has been considered as the several procedures to apprehend the spoken language derived from several experts. Those procedures are including recognizing the speech sounds, understanding the meaning of each word, and understanding the structure of the sentence (Nadig, 2013 in Gilakjani and Sabouri, 2016). Vanderplank (2012) defines listening comprehension as a progressive process where the listeners proceed what they have heard based on their perceptions and their understanding of the theme given. In this case, the listeners are demanded to have good linguistics knowledge such as their knowledge of vocabulary, to create the appropriate meaning from what they have heard from the speaker. Moreover, Lynch (2012) in Azizinia, Sadeghoghli, and Mohebkhah, (2017) gives a different definition of listening comprehension. He states that the skill is defined as the capability to get the message of spoken language of other spoken language.

During the process of listening comprehension, students might face problems. Nonetheless, a few experts explained the definition of listening comprehension problems clearly. As said by Anderson (1995), Goh (2000), Vandergrift (2003), Nowrouzi \& Tam (2015), listening comprehension problem is obstacles that appear at the same time as the process comprehending the spoken text. Bingol, Mart, Celik, and Yildiz (2014) mention that, there are various problems that second or foreign language learner will face. They found some possible issues in the language classroom; they are the quality of the audio 
equipment, cultural differences, accent, unfamiliar vocabulary, the length and speed of the listening, physical condition and the lack of concentration. A study carried by Ghoneim (2013) reveals those advance and intermediate college students facing similar listening comprehension problems with a different ratio. The major listening comprehension problems are lack of background knowledge and recognizing stress in words pronunciation.

Hamouda (2013) divided listening comprehension problems into seven categories. They are problems related to the listening material, the linguistic feature, the concentration failure, the psychology aspects, the listener itself, the speaker, and the physical condition. As reviewed previously, the research on listening comprehension problems focusing on EFL learners at college students resulted in different findings. Due to the reason, this study was carried out. Further, the result expectantly can help teachers to plan and arrange teaching strategies in teaching listening skill.

\section{METHOD}

This research applied a combination of descriptive quantitative and qualitative methods in order to achieve the research aims. The research participants were the first-grade students of a vocational school in Jakarta. This study applied purposive sampling and involved 30 students as the participants consisting of 18 female and 17 male students. Questionnaires, semi structured interview and observation were used as data collecting techniques. The questionnaire was adapted from the previous study conducted by Hamouda (2013). It consists of 26 questions as well as the four Likert scale. The questionnaire was divided into seven categories; problems related to the listening materials, problems related to linguistic features, problems caused by the failure to concentrate, problems related to psychological characteristics, problems related to the listener, and the problems pertaining to physical settings. To make sure the questionnaire was understood by the participants and to avoid misunderstanding, it was translated into Bahasa Indonesia. The interview and observation checklist used as instruments to get the data were adapted from Field (1998); Richards (2008); Karakas (2002), Yildiz, Parjanadze and Albay (2015).

The collected data were divided into three; the data from observation, interview, and questionnaire. The qualitative data from interview and observation were analyzed by means of thematic analysis. In the meantime, the quantitative data from questionnaire were analyzed by means of descriptive analysis of SPPS 23 version. The result provides frequencies, percentages and indicates the major listening comprehension problems (LCP) encountered by the students. The higher percentages of the 'always', 'often', and 'sometimes' of the questionnaire means the higher the LCP encountered by the students.

\section{FINDINGS AND DISCUSSION}

The results of the data collected from students' responses and the result of interview based on the 7 (seven) categories of listening comprehension problems are presented in the form of percentages. Numbers written in parentheses in the tables show the numbers of students who responded to each statement in the questionnaires. The following are the findings and its discussion. 


\section{Problems related to the listening materials}

Listening comprehension problems related listening materials are the first domain of the listening comprehension problems questionnaire. The results of this domain are provided as follows:

Table 1: Questionnaire Results: Problems Related to the Listening Materials

\begin{tabular}{|c|l|c|l|c|c|}
\hline No. & \multicolumn{1}{|c|}{ Statements } & $\begin{array}{c}\text { Always } \\
(\%)\end{array}$ & $\begin{array}{l}\text { Often } \\
(\%)\end{array}$ & $\begin{array}{l}\text { Sometimes } \\
(\%)\end{array}$ & $\begin{array}{l}\text { Never } \\
(\%)\end{array}$ \\
\hline 16. & $\begin{array}{l}\text { Long spoken text interfered with my } \\
\text { listening comprehension }\end{array}$ & $3.3(1)$ & $63.3(19)$ & $33.3(10)$ & 0 \\
\hline 17. & $\begin{array}{l}\text { I find it difficult to interpret the meaning of a } \\
\text { long spoken text. }\end{array}$ & $6.7(2)$ & $43.3(13)$ & $40(12)$ & $10(3)$ \\
\hline 18. & $\begin{array}{l}\text { I find the listening passage difficult to } \\
\text { Understand }\end{array}$ & $10(3)$ & $43.3(13)$ & $40(12)$ & $6.7(2)$ \\
\hline 19. & $\begin{array}{l}\text { I find it difficult to understand listening } \\
\text { texts when the topic is unfamiliar }\end{array}$ & $10(3)$ & $56.7(17)$ & $33.3(10)$ & 0 \\
\hline 20. & $\begin{array}{l}\text { Complex grammatical structures } \\
\text { interfered with my listening comprehension. }\end{array}$ & $6.7(2)$ & $70(21)$ & $20(6)$ & $3.3(1)$ \\
\hline
\end{tabular}

The table shows the percentages of problems pertaining with the length of the material which includes: understanding every word in the listening text, unfamiliar topic, and difficulties of grammar structure. Among those problems related to the listening materials, the understanding of complex grammatical structures becomes the biggest problems for the students; $60 \%$ students confess that they often have the problem.

In addition, the theme which is related to the listening materials also emerged during the interview while the students are asked about the difficulty to understand the listening part. It can be seen in the following interview extract:

I find it hard to understand the speaker when there are many unknown words, and materials with an unfamiliar topic. I actually don't bother if the material is long (3 minutes) as long as I know what the speaker talk about, and I know the meaning of vocabulary mentioned. (Respondent 1)

Long listening material interfere my understanding because I often couldn't remember what the speaker has said. In addition, the unfamiliar topic makes me difficult to predict the upcoming words. The use of unknown words in listening material also worsens my listening comprehension. Sometimes I barely understand the time mentioned by the speakers because of their election of grammar (Respondent 2).

The materials with difficult grammar affect my listening comprehension a lot. Other problems related to the material are the use of difficult vocabulary and the unfamiliar topic. It's hard to understand the listening material if I don't know the topic and a certain word. Moreover, the long listening material is also sometimes hindering my listening comprehension, especially when the speaker talks with a different accent (British) (Respondent 3).

\section{Problems Related to Linguistic Features}

The linguistic feature would affect the students' understandings of the passage. For that reason, the writer gathered four statements to know if students face the difficulties related to 
the linguistic feature.

Table 2: Questionnaire Results: Problems related to Linguistics Features

\begin{tabular}{|c|l|c|c|c|c|}
\hline No. & \multicolumn{1}{|c|}{ Statements } & $\begin{array}{c}\text { Always } \\
(\%)\end{array}$ & $\begin{array}{c}\text { Often } \\
(\%)\end{array}$ & $\begin{array}{c}\text { Sometimes } \\
(\%)\end{array}$ & $\begin{array}{c}\text { Never } \\
(\%)\end{array}$ \\
\hline 9. & $\begin{array}{l}\text { I find it surprising and difficult to deal } \\
\text { with colloquial language and slang }\end{array}$ & $6.7(2)$ & $46.7(14)$ & $36.7(11)$ & $10(3)$ \\
\hline 10. & $\begin{array}{l}\text { I find it difficult to understand reduced } \\
\text { forms }\end{array}$ & $3.3(1)$ & $53.3(16)$ & $26.7(8)$ & $16.7(5)$ \\
\hline 11. & $\begin{array}{l}\text { I do not often pay attention to the } \\
\text { intonation of the speaker }\end{array}$ & $10(3)$ & $53.3(16)$ & $36.7(11)$ & 0 \\
\hline 12. & $\begin{array}{l}\text { I find it difficult to infer the meaning of } \\
\text { an unknown word while listening. }\end{array}$ & $3.3(1)$ & $60(18)$ & $26.7(8)$ & $10(3)$ \\
\hline
\end{tabular}

The table shows the students' responses of problems that they face during listening activities related to the linguistic features. The problems which are related to the linguistic feature consist of colloquial and slang expression, the use of reduced forms, the use of "prosodic features" of the English language, and the problems pertaining to the use of unknown words. Among all the problems, $60 \%$ of students found difficulties to infer the meaning of unknown word while listening.

In addition to the quantitative data, the data from the interview gave more insight towards the students' opinion about the problems related to the linguistics feature. The following extracts of interviews indicate the existence of the problem.

For me, it's the use of slang and reduced forms. Those words make me wonder what it stands for, and it takes a lot of time to think about the meaning of those words (Respondent 1).

When the speaker talks with a British accent, it's hard to catch the intonation. So, I don't do that often. Actually, the use of slang words and reduced forms don't interfere with my listening comprehension (Respondent 3).

\section{Problems Caused by the Failure to Concentrate}

Another factor influencing students' listening comprehension is concentration during listening. This domain consists of three statements about problems pertaining to focus loss resulted from looking for answers, and the problems pertaining to focus loss resulted from thinking about another answer. The results of these 3 questions are presented as follows:

Table 3: Questionnaire Results: Problems Caused by the Failure to Concentrate

\begin{tabular}{|l|l|l|l|l|l|}
\hline No. & \multicolumn{1}{|c|}{ Statements } & $\begin{array}{c}\text { Always } \\
(\%)\end{array}$ & $\begin{array}{l}\text { Often } \\
(\%)\end{array}$ & $\begin{array}{l}\text { Sometimes } \\
(\%)\end{array}$ & $\begin{array}{l}\text { Never } \\
(\%)\end{array}$ \\
\hline 13. & $\begin{array}{l}\text { I lose focus of the talk when I think about the } \\
\text { answer to the question in } \\
\text { my mind }\end{array}$ & $6.7(2)$ & $53.3(16)$ & $36.7(11)$ & $3.3(1)$ \\
\hline 14. & $\begin{array}{l}\text { I am unable to concentrate because I search for } \\
\text { the answer, and I listen to the dialogue at the } \\
\text { same time }\end{array}$ & $6.7(2)$ & $53.3(16)$ & $36.7(11)$ & $3.3(1)$ \\
\hline 15. & $\begin{array}{l}\text { I lose my concentration when I think of another } \\
\text { question }\end{array}$ & $10 \%(3)$ & $66.7(20)$ & $16.7(5)$ & $6.7(2)$ \\
\hline
\end{tabular}


The table gives a picture of the problems caused by the failure to concentrate. Based on the result, most of the students lose their concentration because they think of another question. The second and the third causes that make them lose concentration are thinking about the answer and searching for the answer. They have to do it at the same time as they are listening to the dialogue or text.

Similar to the quantitative data, the problems which are related to the failure to concentrate come into sight in the interview. The students experienced that they often lose their concentration when answering the questions; they were also confused and sometimes forget what to answer. The following interview extracts explain about it.

It (failing to concentrate) usually happens when I try to answer the questions and try to look to other questions. It makes me confused and often forgot the answer because the speaker keeps talking while I have to answer and look to the next questions (Respondents 1).

I often lose my concentration when I'm answering the question and read the questions. To prevent me from answering the wrong answers, I often read the questions when the speaker still gives instructions (Respondent 2).

When the speaker talks too fast, sometimes I have trouble to answer and recognize the question. It's hard to keep up with the conversation because it's toofast and sometimes lost the track (Respondent 3).

\section{Learners' Perceptions of Listening Problems Related to Psychological Characteristics}

This domain is designed to know students' perception about psychological characteristics. The table below shows the result.

Table 4: Questionnaire Results: Learners' Perception of Listening Problems Related to Psychological Characteristics

\begin{tabular}{|l|l|c|c|c|c|}
\hline No. & \multicolumn{1}{|c|}{ Statements } & $\begin{array}{c}\text { Always } \\
(\%)\end{array}$ & $\begin{array}{l}\text { Often } \\
(\%)\end{array}$ & $\begin{array}{c}\text { Sometimes } \\
(\%)\end{array}$ & $\begin{array}{c}\text { Never } \\
(\%)\end{array}$ \\
\hline 1. & $\begin{array}{l}\text { I feel nervous and worried when I } \\
\text { don't understand the spoken text }\end{array}$ & $10(3)$ & $60(18)$ & $23.3(7)$ & $6.7(2)$ \\
\hline 2. & $\begin{array}{l}\text { I find it difficult to understand the spoken text } \\
\text { which is not of interest to me }\end{array}$ & $33 \%(1)$ & $50(15)$ & $46.7(14)$ & 0 \\
\hline
\end{tabular}

The result shows that the nervousness is experienced by $60 \%$ students because they do not understand the spoken text. In addition, the content or topic of the spoken texts which are not interesting for the students become one of causes in listening as well. That is the reason why $50 \%$ students state that they find it difficult to understand when the spoken text is not interesting to them.

The feeling of anxiety before and during the listening activities can cause the problems in understanding the spoken text. As stated in the quantitative data, the anxiety was mentioned in the interview. Kinds of anxiety emerged and became problems to get the meaning and understanding the spoken text but not all of them have those kinds of feeling. The students' answer show how and why the anxiety comes out. It was also found that their interest to the materials can affect their understanding. 
No, I'm not afraid of getting a bad score...... It affects my listening comprehension because the material which is not my interest makes me don't want to listen to it (Respondent 1).

I always do. I'm afraid to make mistakes.......... It affects my listening comprehension a little bit, but I'm still listening to the speaker (Respondent 2).

I'm afraid I don't understand the material (Respondent 3).

Yes. When the material is not matched with my interest, I won't continue to listen (Respondent 4).

\section{Problems related to the listener}

The next domain is the result of listening comprehension problems survey related to the listener. This domain reveals that students think their difficulties in listening comprehension are caused by the students itself. This domain covers 4 items of statements. They are items no. $23,24,25$, and 26 . The problems which are related to the listeners in particular are: difficulty to get a general understanding of the spoken text from the first listening, to predict what would come next, to quick remember words or phrases that just have heard, and when listening to the English spoken text without transcription. The result can be seen in the following table.

Table 5: Questionnaire Results: Problems Related to the Listeners

\begin{tabular}{|l|l|c|c|c|c|}
\hline No. & \multicolumn{1}{|c|}{ Statements } & $\begin{array}{c}\text { Always } \\
(\%)\end{array}$ & $\begin{array}{l}\text { Often } \\
(\%)\end{array}$ & $\begin{array}{l}\text { Sometimes } \\
(\%)\end{array}$ & Jever (\%) \\
\hline 23. & $\begin{array}{l}\text { I find it difficult to get a general } \\
\text { understanding of the spoken text from the first } \\
\text { listening }\end{array}$ & $6.7(2)$ & $60(18)$ & $26.7(8)$ & $6.7(2)$ \\
\hline 24. & $\begin{array}{l}\text { At the time of listening, I found it difficult to } \\
\text { predict what would come } \\
\text { Next }\end{array}$ & $13.3(4)$ & $56.7(17)$ & $26.7(8)$ & $3.3(1)$ \\
\hline 25. & $\begin{array}{l}\text { I find it difficult to quickly remember words or } \\
\text { phrase I have just heard }\end{array}$ & $10(3)$ & $53.3(16)$ & $30(3)$ & $6.7(2)$ \\
\hline 26. & $\begin{array}{l}\text { I find it difficult when listening to English } \\
\text { without transcripts }\end{array}$ & $3.3(1)$ & $56.7(17)$ & $26.7(8)$ & $13.3(4)$ \\
\hline
\end{tabular}

The percentages show that most of students $(60 \%)$ have difficulties to get general understanding of the spoken text from the first listening among other difficulties. Sequences to that, the students are struggling to predict what would come next and when they are listening without transcription. Afterwards, the quick remembering words or phrases that have just heard are the next difficulty related to listeners.

Referring to the data, it can be seen from the interview that the problem can be from the listener. It is related to the problems of pertaining to memory and the absence of transcription. The answers show how the difficulties in listening happened during the listening activity.

I often forget what the speaker just said. It's like when I want to answer the question, but the speaker kept talking. It interfered me and made me forget. I also find it difficult to 
understand the speaker without a transcript. Reading the dialogue during listening makes me understand the material better (Respondent 1).

Sometimes I forget what the speaker has just said, especially when the material is too long. And also, the teacher usually doesn't give us the transcript whereas I prefer to listen and read the text to prevent me from misunderstanding (Respondent 2 ).

Forgetting the speaker utterance, it happens often. I also find it easier to understand if the teacher gives us the transcript (Respondent 4).

The result shows that the failure to remember what they have just listened because of the length of listening materials. The transcription which was provided after listening activity can help them to evaluate their understanding.

\section{Problems related to the speaker}

During listening activities, students often face difficulties related to the speaker. Based on the table below, the speaker is also one of factors that interferes students listening comprehension. The speaker can be the cause of difficulty because of the hesitation and pauses, the unclear pronunciation, the absence of the speakers' body language, the variety of accents, the speed, and of no repetition.

Table 6: Questionnaire Results: Problems Related to the Speaker

\begin{tabular}{|c|l|c|c|c|c|}
\hline No. & \multicolumn{1}{|c|}{ Statements } & $\begin{array}{c}\text { Always } \\
(\%)\end{array}$ & $\begin{array}{l}\text { Often } \\
(\%)\end{array}$ & $\begin{array}{c}\text { Sometimes } \\
(\%)\end{array}$ & $\begin{array}{c}\text { Never } \\
(\%)\end{array}$ \\
\hline 3. & $\begin{array}{l}\text { I find it difficult to understand the } \\
\text { natural speech which is full of hesitation and } \\
\text { pauses }\end{array}$ & $3.3(1)$ & $46.7(14)$ & $50(15)$ & 0 \\
\hline 4. & $\begin{array}{l}\text { I find it difficult to understand the meaning of } \\
\text { words which are not pronounced clearly }\end{array}$ & $20(6)$ & $40(12)$ & $30(9)$ & $10(3)$ \\
\hline 5. & $\begin{array}{l}\text { I find it difficult to understand the meaning of } \\
\text { the spoken text without } \\
\text { seeing the speaker's body language }\end{array}$ & $13.3(4)$ & $40(12)$ & $43.3(13)$ & $3.3(1)$ \\
\hline 6. & $\begin{array}{l}\text { I find it difficult to understand well } \\
\text { when speakers speak with a variety of accents }\end{array}$ & $10(3)$ & $46.7(14)$ & $33.3(10)$ & $10(3)$ \\
\hline 7. & $\begin{array}{l}\text { I find it difficult to understand well when the } \\
\text { speaker speaks too fast }\end{array}$ & $16.7(5)$ & $60(18)$ & $20(6)$ & $3.3(1)$ \\
\hline 8. & $\begin{array}{l}\text { I find it difficult to understand the recorded } \\
\text { material if I am unable to get things repeated }\end{array}$ & $10(3)$ & $56.7(17)$ & $30(9)$ & $3.3(1)$ \\
\hline
\end{tabular}

The table shows that the majority of the students who were participated in the research stated that when the speaker speaks too fast, they often cannot understand well. There are $60 \%$ students that have the same problem. Sequence to that, the material which cannot be repeated has also become a problem. The hesitation and pauses can also be comprehension problem of listening. The earlier has the higher percentages rather than the latter as well as the absence of the speakers' body language and the variety of the accent. 
The eighth question was asked to know students' listening comprehension problems pertaining to the speaker. From the results above, it seems that all four participants had similar problems. The following answers relate to the quantitative data.

The problems related to the speaker are the speaker's accent and the speaker speed rate in speaking. I find it hard to understand the speaker's British accent because I'm more familiarized with American accents. Moreover, when the speaker is talking at a fast speed, it's hard to catch the meaning. I also prefer to listen twice or more because I often forget what the speaker said (Respondent 1).

I think speaker's accent is the major problems related to the speaker for me. Two weeks ago we were given a listening exercise with a British accent. It's difficult to understand, I prefer listening to an American accent. Moreover, during listening, I find it difficult to understand the spoken language when it's played without repetition. It is better to listen two or three times to make sure I get the meaning correctly (Respondent 2).

The biggest problem is the speaker accents. I'm getting used to listening to American language, so it's hard to understand British or others accents. Speaker talks with high speed also worsen my listening comprehension as well (Respondent 3).

Actually, I experience some problems because I don't understand English well. The problem related to the speaker is maybe the unclear speaker's pronunciation. When the speaker's pronunciation unclear, it makes me don't want to listen to it anymore. The speed of the speaker's delivery is also causing a problem. It hinders my listening comprehension (Respondent 4).

Further, the visual of speakers' body language or any other visual support can be helpful for students to understand. The question was asked to know whether the inability to see visual supports such as body language and lips movement will affect students' listening comprehension. The following interview extracts show the students opinion.

... but when I see the lips movements. It helps me to understand (Respondent 1).

...Quiet important. I can see the lips move. It makes me easier to understand (Respondent 3).

... it's easier to understand when we could see the speaker's lips movement (Respondent 4).

\section{Problems pertaining to physical settings}

Besides the problems that had been mentioned above, problems related to the physical setting are also hinder students' listening comprehension. The results are presented as follows: 
Table 7: Questionnaire results: Problems Pertaining to Physical Settings

\begin{tabular}{|c|l|c|c|c|c|}
\hline No. & Statements & $\begin{array}{c}\text { Always } \\
(\%)\end{array}$ & $\begin{array}{c}\text { Often } \\
(\%)\end{array}$ & $\begin{array}{c}\text { Sometimes } \\
(\%)\end{array}$ & $\begin{array}{c}\text { Never } \\
(\%)\end{array}$ \\
\hline 21. & $\begin{array}{l}\text { It is difficult for me to concentrate } \\
\text { with noises around }\end{array}$ & $23.3(7)$ & $46.7(14)$ & $26.7(8)$ & $3.3(1)$ \\
\hline 22. & $\begin{array}{l}\text { Unclear sounds resulting from poor equipment } \\
\text { interfere with my listening comprehension }\end{array}$ & $16.7(5)$ & $53.3(16)$ & $30(9)$ & 0 \\
\hline
\end{tabular}

The physical surrounding has contribution to the students' comprehension problems either. Based on the questionnaire, it was found that $53,3 \%$ students state that the unclear sounds from the poor equipment often interfere their listening comprehension as well as the noises with $46,7 \%$ students experienced the problem.

The two questions which were asked in order to know students' listening comprehension problem related to physical setting. The first question is asked to consider problems associated with the noisy surroundings. The second question is asked to examine students problems linked to the equipment that is provided during listening. Related to the noisy, the students stated that it failed them to concentrate to get the meaning of the spoken text. It can also be because of the poor equipment which was provided during listening.

Instead of questionnaires and interview, it was also carried out an observation. The observation was employed to verify the result of questionnaires and interview. Physical settings are the major problems encountered by the students. The students find it difficult to catch the meaning of the English spoken text when their surrounding is noisy. Those noises usually appear from outside or inside the classroom. The findings reveal that many students keep talking during listening and it makes others' concentration get interrupted. In addition, the problem related to the listening equipment also hinders students understanding of the spoken text. The students usually do the listening activity in the classroom due the language laboratory weren't in good condition. The other major problem faced by the students is failing in concentrate. The students find it hard to concentrate during listening where they need to answer the questions, yet listen to the speaker at the same time. Moreover, students consider a material with an unfamiliar topic and unknown vocabulary could be their major problems in listening.

The problems mentioned above are in line with a study about listening comprehension problems conducted by Bingol, Mart, Celik, \& Yildiz, (2014). In the research, they found that physical surroundings such as noises around and the quality of the listening equipment hindered students' listening comprehension. Moreover, those researchers explain that lack of concentration and unfamiliar topic and vocabulary can be the major listening comprehension problems encountered by the students.

Additionally, it was also found others listening comprehension problems suffered by the students. According to the data analysis, problems pertaining to the length of spoken text are one of the listening comprehension problems students experienced during listening. The students said that long material would create confusion. The other problems are the speaker's speed rate of delivery and the various accents. Students think that understand the speaker who talks too fast is difficult. Especially when the speaker uses an accent they are not familiar with. 
In this case, the students were not familiar with the British accent. This result is supported by a study conducted by Renandya \& Farrell (2011) which the results expose main resource of students' listening comprehension problems is the fast rate of speech.

Further, the result of this present study indicates that slang words and uninteresting listening topic are the others students' listening comprehension problems. Students stated that slang words will waste their time while thinking of its meaning. In consequence, the students often miss some parts of the conversation. It also does the same with the uninteresting listening topic. Some students admit that listening texts can cause decrease their excitement and can cause them to lose the track or worse, they do not want to listen anymore.

To lay the final thesis over the final findings above, it can be concluded that there are three major problems of listening comprehension among vocational school students. The first is the physical setting such as noises around, the unclear sounds resulting from low quality equipment. The second is failure in concentrating which was caused by the distractions in the listening. The third is the listening materials which are long and contain unfamiliar vocabularies and topics.

\section{CONCLUSION}

Based on to the data in exploring listening comprehension problems, all of the students experience some problems in understanding the spoken text. There are seven major problems in students' listening comprehension, they are: noises around, poor quality equipment, unfamiliar topic, lack of vocabulary, long spoken text, high speed of delivery, and unfamiliar accents. Therefore, it can be concluded that listening comprehension can be affected by internal and external factors. In this case, problems related to the physical condition, listening material, the speaker, and the listener itself could be the most factor which can causing students facing some difficulties in comprehending the listening. Thus, students need to improve their listening comprehension by using strategies based on their problems to prevent misunderstanding in listening comprehension and to understand the spoken language better.

\section{REFERENCES}

Azizinia, H., Sadeghoghli, H., \& Mohebkhah, V. (2017). A Study of English Listening Comprehension Improvement via Product- vs Process-Oriented Tactics: The Case Study of Shiraz EFL Learners. (2013), 22-31.

Bell, J. (2010). Doing Your Research Project. In Social Science. Retrieved from http://www.myilibrary.com?ID=94698

Bingol, M. A., Mart, C. T., Celik, B., \& Yildiz, N. (2014). Listening comprehension difficulties encountered by students in second language learning class. Journal of Educational and Instructional Studies in the World, 4(4), 25-30.

Bloomfield, A., Wayland, S. C., Rhoades, E., Blodgett, A., Linck, J., \& Ross, S. (2010). "What makes listening difficult." In Factors affecting second language comprehension (pp. 1-119).

Cubalit, A. N. (2016). Listening comprehension problems of Thailand English learners. Proceedings of the Third International Conference on Language, Literature \& Society, 207-214. 
Ghoneim, N. M. M. (2013). The listening comprehension strategies used by college students to cope with the aural problems in EFL classes: An analytical study. English Language Teaching, 6(2), 100-112. https://doi.org/10.5539/elt.v6n2p100

Gilakjani, Abbas Pourhosein, \& Sabouri, N. B. (2016). Learners' Listening Comprehension Difficulties in English Language Learning: A Literature Review. Canadian Center of Science and Education, 9(6), 123-133. https://doi.org/10.5539/elt.v9n6p123

Gilakjani, Abbas Pourhossein, \& Ahmadi, M. R. (2011). A study of factors affecting EFL learners' English listening comprehension and the strategies for improvement. Journal of Language Teaching and Research, 2(5), 977-988. https://doi.org/10.4304/jltr.2.5.977- 988

Hamouda, A. (2013). An investigation of listening comprehension problems encountered by Saudi students in the EL listening classroom. International Journal of Academic Research in Progressive Education and Development, 2(2), 2226-6348.

Hwaider, S. M. (2017). Problems of Teaching the Listening Skill to Yemeni EFL Learners. International Journal of Scientific and Research Publications, 7(6), 140-148.

Nowrouzi, S., \& Tam, S. S. (2015a). Iranian EFL students' listening comprehension problems. Theory and Practice in Language Studies, 5(2), 263-269.

Nowrouzi, S., \& Tam, S. S. (2015b). Iranian EFL Students' Listening Comprehension Problems. Theory and Practice in Language Studies, 5(2), 263-269. https://doi.org/10.17507/tpls.0502.05

Rajab, S. Y., \& Nimehchisalem, V. (2016). Listening comprehension problems and strategies among Kurdish EFL learners. Iranian EFL Journal, 12(4), 6-27.

Renandya, W. A., \& Farrell, T. S. C. (2011). "Teacher, the tape is too fast!" Extensive listening in ELT. ELT Journal, 65(1), 52-59. https://doi.org/10.1093/elt/ccq015

Richards, J. C. (2008). Teaching Listening and Speaking: From Theory to Practice. In Language Teaching (Vol. 35). https://doi.org/10.1017/S0261444802211829

Vanderplank, R. (2012). Teaching and Learning Second Language Listening: Metacognition in Action. System, 40, 567-569. https://doi.org/10.1016/j.system.2012.10.004

Yagang, F. (1993). No Title. In Teacher Development: Making the Right Moves.

Yildiz, N., Parjanadze, N., \& Albay, M. (2015). The Effect of Question Position on Listening Comprehension: A Case Study. 2(1), 4-9. 